\title{
TINJAUAN TAMPILAN VISUAL DESAIN KEMASAN ROTI MURNI DI YOGYAKARTA
}

\author{
Sudjadi Tjipto $\mathbf{R}^{\mathbf{1}}$, Rossa Dyana Pramusita ${ }^{2}$ \\ Program Studi Desain Komunikasi Visual \\ Sekolah Tinggi Seni Rupa dan Desain Visi Indonesia - Yogyakarta \\ Sudjadi1980@gmail.com ${ }^{1}$, dyana.kho@gmail.com ${ }^{2}$
}

\begin{abstract}
Abstrak
Kemasan pada saat ini telah mengalami penambahan fungsi dimana kemasan tidak lagi sekedar untuk melindungi dan sebagai wadah, tetapi juga berfungsi sebagai media promosi serta komunikasi sebuah produk. Kini desain kemasan telah menjadi bagian penting dalam proses pemasaran. Penelitian ini mengambil objek kajian kemasan Roti Murni di Yogyakarta yang sudah lama tidak mengalami perubahan desain kemasannya. Tujuan dari penelitian adalah untuk mengetahui latar belakang desain kemasan Roti Murni yang sudah lama tidak mengalami perubahan dan meninjau kemasan kardus Roti Murni dengan teori kemasan Desain Komunikasi Visual. Metodologi penelitian kualitatif digunakan dengan sumber data yang diperoleh dengan cara observasi dan wawancara. Data penelitian kemudian dianalisis dengan teknik analisis komponensial menggunakan teori warna, bentuk, ilustrasi, tipografi, dan tata letak menurut Desain Komunikasi Visual. Dari hasil penelitian ditemukan fakta yang menarik bahwa kemasan Roti Murni tidak berubah karena perusahaan tidak memiliki desainer kemasan, dan desain kemasannya tidak secara keseluruhan sesuai dengan teori DKV.
\end{abstract}

Kata kunci: Kemasan, Roti Murni, Tampilan Visual, Yogyakarta

\begin{abstract}
Packaging at this time is indicating to have some additional functions where the packaging is no longer simply to protect or just as a container of a product inside, but also serves as a media campaign of a product inside. Packaging design then has become an important part of the marketing process. The object of this study is the packaging design used by "Roti Murni", one of bakery companies in Yogyakarta. The packaging design used by "Roti Murni" has been known that it has not been changed since long time ago. The purpose of the study is to determine the background of "Roti Murni" packaging design that has not changed and to review the design of the packaging with the theory of Visual Communication Design. This study is using qualitative research methodology, while the source data analized were obtained by observation and interviews. Data were analyzed with componential analysis techniques using the theory of color, shape, illustration, typography, and layout in Visual Communication Design. The research found an interesting fact that the packaging of "Roti Murni" has not changed since the company does not have packaging designers, and the overall packaging design itself was not designed by using the theory of Visual Communication Design.
\end{abstract}

Keywords: Packaging, Murni Bakery, Visual Review, Yogyakarta 


\section{PENDAHULUAN}

Kegiatan mengemas sudah dikenal dan dilakukan oleh manusia sejak 8000 SM. Pada masa itu manusia menggunakan daun, kulit binatang, dan bahan-bahan alami yang lain sebagai kemasan (Klimchuk, 2006:1). Semasa itu kemasan hanya dilihat dari segi fungsinya dimana tampilan visual tidak merupakan hal yang penting. Seiring dengan perkembangan teknologi ketika produk-produk yang dijual semakin beragam, fungsi kemasan turut berkembang. Kemasan tidak lagi hanya berfungsi sebagai wadah dan pelindung produk, tetapi berfungsi pula sebagai media promosi serta media informasi yang menunjukkan identitas perusahaan. Kini semua produk yang dijual sudah menggunakan kemasan dengan beragam material, termasuk juga kemasan Roti Murni (Murni Bakery) Yogyakarta. Dari hasil wawancara dengan sang pemilik; Murni Bakery berdiri sejak tahun 1985. Roti Murni merupakan salah satu perusahaan roti "tua" dan tetap bertahan di Yogyakarta hingga kini. Beragam jenis roti yang menjadi ciri khas Roti Murni adalah kue sus, muffin, mandarin, dan tart.

Di Yogyakarta brand Roti Murni sudah sangat kuat, Roti Murni identik dengan kelas menengah dan lazim digunakan sebagai hidangan konsumsi rapat-rapat atau pertemuan instansi (kantor pemerintahan/swasta, perguruan tinggi, atau organisasi) dan acara kegiatan pertemuan warga (arisan, tasyakuran atau kematian). Desain dan warna kuning khas kemasan Roti Murni sangat mudah dikenali, sejak tahun 1980-an hingga kini desain kemasan Roti Murni tidak berubah, perihal inilah yang kemudian menjadi landasan utama penelitian. Pertanyaan penelitian kemudian mengerucut pada alasan kenapa tampilan visual kemasan Roti Murni tidak berubah? Apakah kemasan Roti Murni sudah sesuai dengan teori Desain Komunikasi Visual?

\section{TINJAUAN PUSTAKA}

\subsection{Desain Kemasan}

Sejarah desain kemasan diawali dengan kebutuhan manusia untuk menyimpan barang. Sejak 8000 SM manusia membuat kemasan dengan menggunakan material-material alami seperti anyaman rumput, kulit pohon, daun, kerang, kerajinan tanah liat, dan peralatan kaca yang kasar sebagai wadah barang-barangnya (Klimchuk, 2006:1). Menurut paparan Sri Julianti (2014:9), sejarah kemasan di Indonesia tidak jauh berbeda perkembangannya dengan kemasan di dunia. Bahan kemasan yang umum digunakan di Nusantara adalah daun, kayu, bambu, gerabah, kertas, kaca, gelas, dan kaleng.

Terdapat beragam definisi dari kata mengemas, kemasan, dan desain kemasan. Mengemas merupakan tindakan membungkus suatu barang atau sekelompok barang (Klimchuk, 2006:34). Sedangkan menurut Julianti (2014:15). Klimchuk dan Krasovec (2006:34) memaparkan bahwa kemasan mengacu pada objek fisik kemasan itu sendiri. Kata "kemasan" mengimplikasikan hasil akhir proses mengemas, sehingga kemasan adalah wadah berupa hasil akhir proses mengemas untuk meningkatkan nilai dan fungsi sebuah produk. 


\subsection{Teori Komunikasi Visual Desain Kemasan}

Perihal unsur warna dalam desain kemasan, Wirya (1999:26) menyatakan bahwa, warna adalah suatu mutu cahaya yang dipantulkan dari suatu objek ke mata manusia. Konsumen melihat warna lebih cepat daripada bentuk atau rupa. Warna dengan daya pantul tinggi akan lebih terlihat dari jarak jauh dan direkomendasikan bagi sebagian besar kemasan karena daya tariknya lebih besar. Sementara Klimchuk dan Krasovec (2006:107) menyatakan bahwa warna dapat mengidentifikasikan sebuah merk. Penggunaan yang tepat dapat menerobos kategori produk dan mendiferensiasi ragam produk-komposisi, rasa, atau bau-dalam suatu lini produk. Sedangkan dari segi bentuk kemasan Wirya (1999:29-30) menyatakan bahwa bentuk kemasan merupakan pendukung utama yang membantu terciptanya seluruh daya tarik visual. Tidak ada prinsip baku yang menentukan bentuk fisik dari sebuah kemasan karena biasanya ditentukan oleh sifat produk, pertimbangan mekanis, kondisi penjualan, pertimbangan pemajangan, dan cara penggunaan kemasan. Bentuk kemasan yang sederhana, teratur menjadi lebih praktis dan disukai konsumen.

Tipografi dalam desain kemasan merupakan media utama untuk mengkomunikasikan sebuah nama, fungsi, dan fakta produk bagi konsumen secara luas. Tipografi adalah penggunaan bentuk huruf untuk mengkomunikasikan secara visual suatu bahasa lisan. Kemudahan untuk dibaca, dikenali, waktu bacaan, ukuran, bentuk, dan gaya, semuanya merupakan karakteristik tipografi yang mempengaruhi komunikasi pada sebuah kemasan (Klimchuk, 2006:87). Lebih mendalam Klimchuk dan Krasovec (2006:88-89), mengolongkan huruf menjadi 6 tipe, yaitu:

a. Old Style: meliputi Times New Roman, Bembo, Palatino, Goudy, New Baskerville, Garamond, dan Janson.

b. Modern/Serif: meliputi Bodoni, Times, Fenice, dan Madrone.

c. Slab Serif/ Egyptian/ Square Serif: meliputi Clarendon, New Century Schoolbook, Memphis, Rockwell, dan Aachen.

d. Sans Serif: meliputi Gill Sans, Franklin Gothic, Helvetica, dan Futura.

e. Script: meliputi Zapf Chancery dan Edwardian Decorative.

f. Decorative: huruf ini memiliki estetika dekoratif dan tidak didesain untuk mudah dibaca.

Apabila diamati dengan seksama sebuah kemasan juga memiliki tata letak yang menjadi ciri khas produknya. Wirya (1999:35-36) memaparkan bahwa tata letak adalah keterampilan meramu semua unsur grafis meliputi warna, bentuk, merk, ilustrasi, tipografi, menjadi satu kesatuan baru yang disusun dan ditempatkan pada sebuah halaman kemasan secara utuh dan terpadu. Ada 6 hal yang perlu dipertimbangkan bagi pengembangan tata letak yaitu keseimbangan, titik pandang, kontras, proporsi, alunan pirza (penataan seluruh elemen visual dengan urutan paling logis), dan kesatuan.

\section{METODE PENELITIAN}

Metode penelitian yang digunakan dalam penelitian kemasan ini adalah metode penelitian kualitatif. Prosedur penelitian yang telah dilakukan adalah dengan mengobservasi data penelitian berupa kemasan Roti Murni, menyusun hipotesis, 
melakukan wawancara, mendokumentasikan dan menyusun data, serta membandingkan data dengan teori DKV untuk menghasilkan simpulan. Observasi yang telah dilakukan adalah observasi tidak berstruktur dimana observasi dilakukan tanpa menggunakan guide observasi. Peneliti harus mampu secara pribadi mengembangkan daya pengamatannya dalam mengamati suatu objek (Bungin, 2007:120). Dilanjutkan dengan wawancara terstruktur dengan pemilik Roti Murni. Menurut Bungin, bentuk wawancara terstruktur dilakukan secara bebas dan juga mendalam tetapi tidak terlepas dari pokok permasalahan yang akan ditanyakan kepada responden dan telah dipersiapkan sebelumnya oleh pewawancara (Bungin, 2007:113). Sedangkan metode analisis yang digunakan adalah Teknik Analisis Komponensial, Bungin (2007:216-220) menjelaskan bahwa Teknik Analisis Komponensial adalah teknik analisis yang paling mudah dilakukan karena menggunakan "pendekatan kontras antarelemen". Analisis Komponensial berupa kajian pada desain grafis kemasan Murni yang dianalisis menggunakan teori warna, bentuk, tipografi, dan tata letak menurut Desain Komunikasi Visual.

\section{DATA DAN ANALISA}

\subsection{Kemasan Murni Bakery}

Perusahaan Roti Murni didirikan pada tahun 1952 oleh Ibu Laksmi Kirana Murni. Nama perusahaan saat itu adalah "Merpati" dengan tujuan agar roti kering Ibu Laksmi dikenal sebagai roti Merpati. Sekitar tahun 1970, perusahaan Merpati diteruskan oleh Pak Soerjono (Sie Kie Siong) yang merupakan menantu dari Ibu Laksmi. Mereka memulai produksi dengan membuat roti basah yang diberi merek dagang "Murni" (diambil dari nama Ibu Laksmi Kirana Murni) sedangkan roti kering diberikan merk Merpati. Dari hasil wawancara dengan Pak Soerjono diperoleh informasi bahwa nama "Merpati Murni Bakery" berasal dari gabungan dua nama yaitu Merpati dan Murni. Tetapi nama paten di departemen kehakiman adalah Murni dengan logo Merpati. Makna dari nama Merpati tidak diketahui, tetapi bentuk bola dunia yang terdapat pada logo Murni Bakery memiliki makna harapan supaya Murni Bakery bisa mengglobal.

Dalam mengemas produknya, Murni bakery memiliki beberapa kemasan; yaitu: kemasan kardus, kemasan plastik, dan tas plastik. Semua kemasan mulai digunakan sejak tahun 1980-an dan belum pernah diganti atau diubah hingga sekarang. Tidak diketahui siapa yang mendesain kemasan Murni Bakery karena sudah tidak diingat oleh Pak Soerjono. Kemasan dicetak di percetakan yang berbeda di kota Semarang kemasan dicetak di Setiawan Screen, Kezia, dan Mulia Offset, sedangkan untuk kemasan kardus, Murni Bakery mencetak di percetakan Lendis Yogyakarta. Diperoleh fakta yang menarik bahwa Murni Bakery tidak pernah mengganti desain kemasan dikarenakan mereka tidak memiliki divisi desain kemasan. Kemasan kardus yang digunakan Murni Bakery memiliki 3 warna utama yaitu; kuning, oranye, dan cokelat. Bahan kardus dipilih karena sudah umum digunakan untuk mengemas makanan. Selain itu, kardus dinilai lebih prestise sehingga ketika konsumen membeli untuk digunakan sebagai pemberian atau rapat akan terlihat lebih pantas dan sopan. Murni Bakery memiliki 14 macam kemasan kardus roti dengan berbagai ukuran dan fungsi. Berikut 
adalah tabel dokumentasi kemasan kardus roti Murni Bakery beserta ukuran dan fungsinya:

Tabel 1. Data teknis Kardus Kemasan Murni Bakery

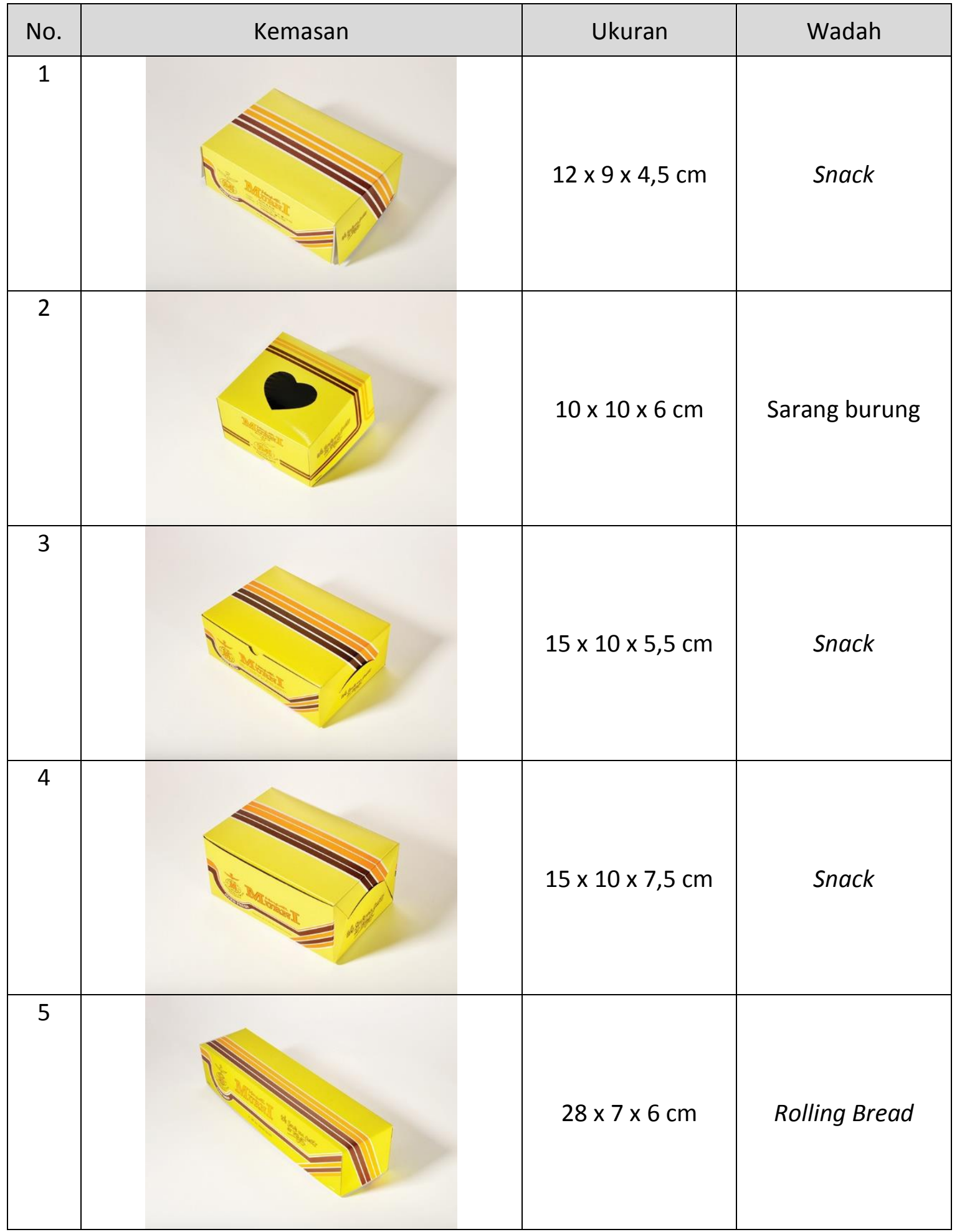




\begin{tabular}{|c|c|c|c|}
\hline No. & Kemasan & Ukuran & Wadah \\
\hline 6 & & $12,5 \times 16,5 \times 7 \mathrm{~cm}$ & Snack \\
\hline 7 & & $25 \times 16,5 \times 7 \mathrm{~cm}$ & Snack \\
\hline 8 & & $22 \times 22 \times 8 \mathrm{~cm}$ & Kue Mandarin \\
\hline 9 & & $24 \times 24 \times 7 \mathrm{~cm}$ & Snack \\
\hline 10 & & $27 \times 27 \times 8 \mathrm{~cm}$ & Snack \\
\hline
\end{tabular}




\begin{tabular}{|c|c|c|c|}
\hline No. & Kemasan & Ukuran & Wadah \\
\hline 11 & & $25 \times 25 \times 10 \mathrm{~cm}$ & Tart mini \\
\hline 12 & & $30 \times 30 \times 12 \mathrm{~cm}$ & Tart bolu \\
\hline 13 & & $40 \times 40 \times 15 \mathrm{~cm}$ & Tart besar kotak \\
\hline 14 & & $53 \times 39 \times 15 \mathrm{~cm}$ & $\begin{array}{c}\text { Tart besar } \\
\text { panjang }\end{array}$ \\
\hline
\end{tabular}

\subsection{Analisis Warna Kemasan Murni Bakery}

Warna yang digunakan pada kemasan kardus roti Murni Bakery adalah kuning, oranye, coklat, dan putih. Dari hasil wawancara dengan Pak Soerjono, beliau mengatakan bahwa warna yang digunakan merupakan warna yang mengacu pada warna bahan makanan (pembuat adonan dasar roti). Seperti warna kuning yang mewakili kuning telur, oranye mewakili keju, dan coklat mewakili buah coklat. Dari hasil simpulan wawancara tersebut kemudian dibuat tabel perbandingan makna warna kemasan versi Murni Bakery dengan versi teori warna DKV menurut Wirya (1999:58-69) serta Klimchuk \& Krasovec (2006:108), dengan hasil analisis sebagai berikut: 
Tabel 2. Perbandingan Makna Warna kemasan versi Roti Murni dengan Teori Warna DKV

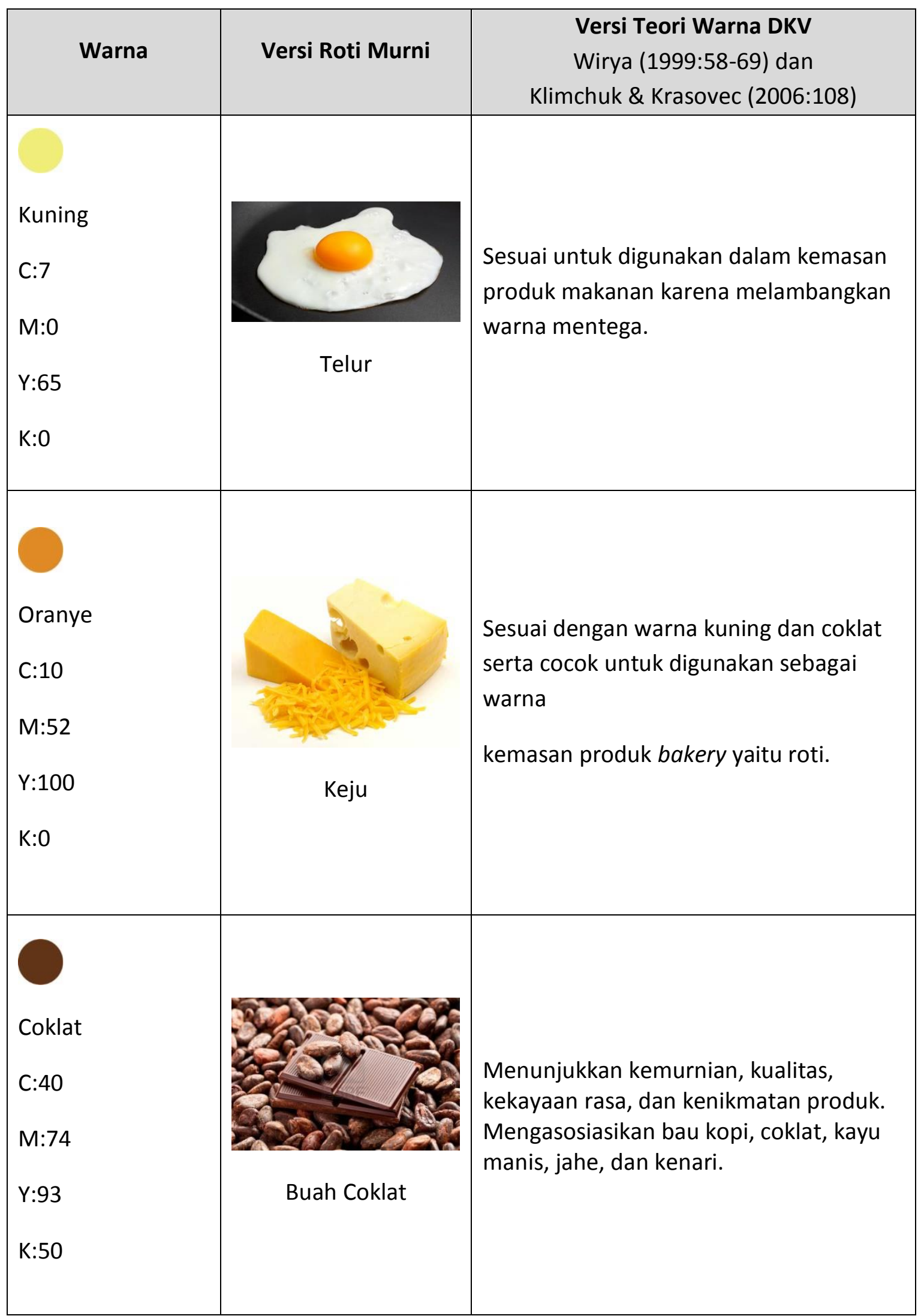


Warna kuning pada kemasan Murni digunakan sebagai latar belakang atau background sehingga warna kuning tampak dominan. Menurut Wirya (1999:58-62), warna kuning merupakan warna istimewa untuk pengemasan karena memiliki keterlihatan tinggi serta tepat dikombinasikan dengan warna oranye dan coklat. Selain itu, warna kuning sesuai untuk digunakan dalam kemasan produk makanan. Warna kuning dapat diidentifikasikan sebagai warna mentega dan keju. Tetapi terlalu banyak kuning pucat dapat menimbulkan kesan bahwa produk kurang enak. Dari segi proteksi terhadap efek cahaya, warna kuning dapat memantulkan panas dengan baik sehingga produk terlindungi. Sedangkan menurut Klimchuk dan Krasovec (2006:108), warna kuning melambangkan kehidupan, matahari, kehangatan, dan energi. Warna kuning juga merupakan warna yang paling menarik perhatian, dalam produk pengemasan makanan, warna kuning sering dipakai untuk mengkomunikasikan rasa jeruk/mentega.

Kesimpulannya penggunaan warna kuning cocok untuk digunakan pada kemasan produk makanan karena melambangkan warna mentega dan dapat menarik perhatian konsumen dengan baik. Jadi penerapan warna kuning pada kemasan kardus roti Murni Bakery sudah tepat.

Kemasan kardus Murni menggunakan warna oranye pada motif garis, logo Murni, dan tulisan "Merpati MURNI". Menurut Wirya (1999:63), warna oranye merah merupakan warna terbaik untuk pengemasan makanan. Warna oranye sangat dinamis, menyenangkan, dan memiliki daya tarik impuls yang tinggi. Warna oranye sesuai untuk digunakan dalam pengemasan produk makanan seperti produk bakery, roti, serelak, makanan bayi, dan daging. Sedangkan menurut Klimchuk dan Krasovec (2006:108), warna oranye dapat mengkomunikasikan merek yang kuat dan energik, serta dapat mengkomunikasikan rasa segar, pedas, atau rasa buah-buahan. Warna oranye sudah diterapkan dengan baik pada kemasan kardus roti Murni Bakery sebab penggunaan warna oranyenya tidak terlalu banyak dan sesuai untuk pengemasan produk bakery.

Selain warna kuning dan oranye, kemasan Murni juga menggunakan warna coklat pada motif garis, sebagai warna teks dan outline, serta pada logo Murni. Menurut Wirya (1999:66-69), warna coklat merupakan warna alamiah bahan makanan seperti coklat, kopi, dan kacang. Warna coklat dapat digunakan ketika perlu menunjukkan rasa enak dan kemurnian. Walaupun warna coklat bukanlah warna yang menarik perhatian tetapi mampu menunjukkan kualitas, kekayaan rasa, dan kenikmatan produk. Hal ini menunjukkan bahwa warna coklat cocok untuk diterapkan pada kemasan produk bakery karena dapat mengasosiasikan bau kopi, coklat, kayu manis, jahe, dan kenari. Warna coklat juga menunjukkan kekayaan rasa sehingga mendukung produk Murni dengan baik. Sedangkan menurut Danger (1992:246-247), warna coklat merupakan warna alamiah bahan makanan, seperti coklat, kopi, kacang. Coklat adalah warna yang membumi, menenangkan, menentramkan. Coklat sangat serasi dengan warna kuning, dan nampak indah dengan hijau. Aplikasi pada kemasan direkomendasikan bila terdapat hubungan dengan produknya, seperti; kopi, coklat, dan produk roti. 


\subsection{Analisis Bentuk Kemasan Murni Bakery}

Berdasarkan wawancara yang telah dilakukan dengan Pak Soerjono (Sie Kie Siong) pemilik Murni Bakery, beliau sudah tidak dapat mengingat lagi siapa yang telah membuat desain untuk kemasan Murni Bakery. Hal ini terjadi dikarenakan Murni Bakery tidak memiliki divisi khusus desain kemasan. Hal ini membuat Murni Bakery tidak terlalu mengutamakan tampilan visual (Desain) pada kemasan, pertimbangannya hanya sebatas pada fungsi kemasan yang mampu melindungi dan sebagai wadah yang memudahkan roti saat dibawa.

\section{Infografis Kemasan Kardus Murni Bakery}
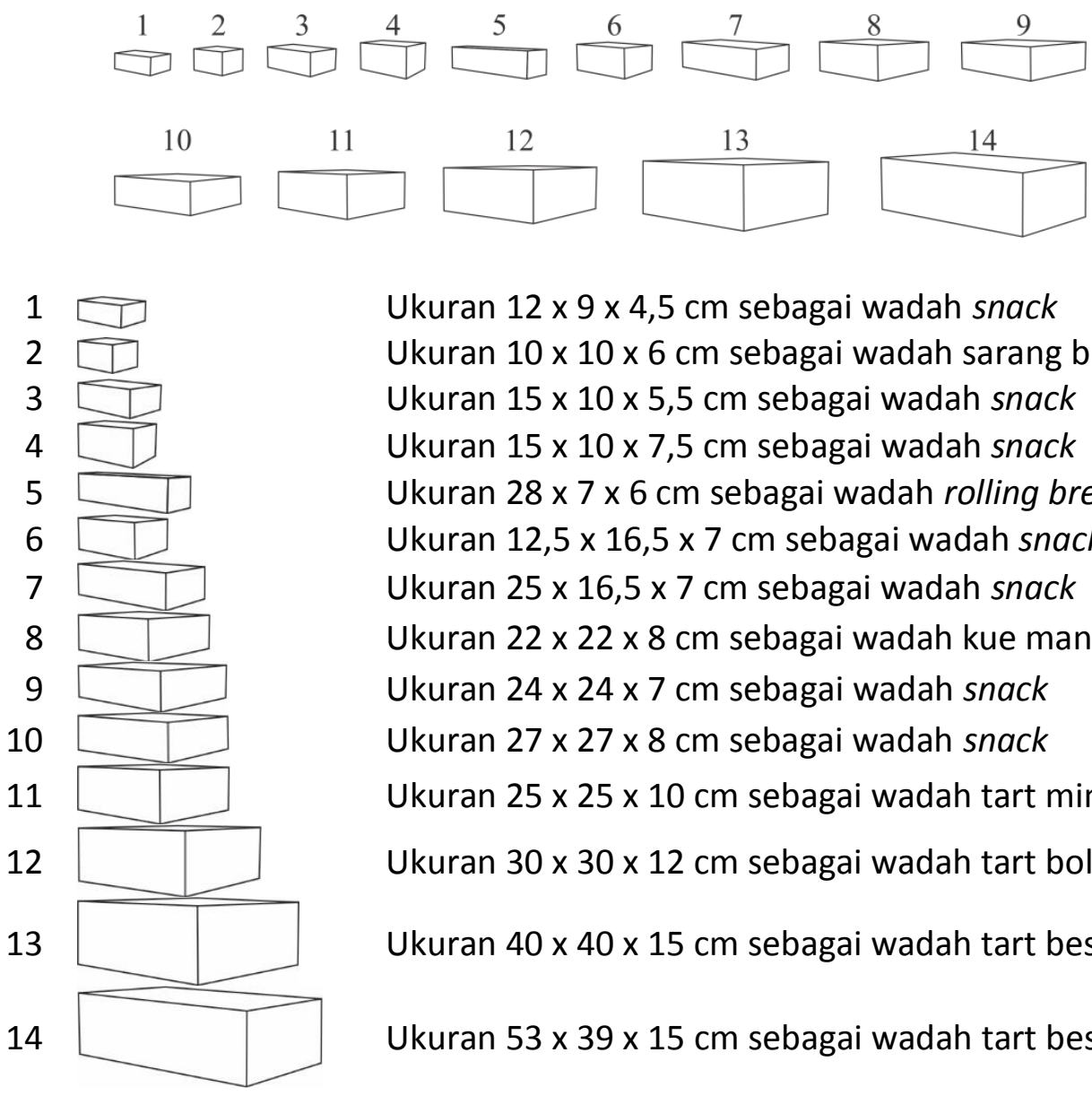

Ukuran $12 \times 9 \times 4,5 \mathrm{~cm}$ sebagai wadah snack Ukuran $10 \times 10 \times 6 \mathrm{~cm}$ sebagai wadah sarang burung Ukuran $15 \times 10 \times 5,5 \mathrm{~cm}$ sebagai wadah snack Ukuran $15 \times 10 \times 7,5 \mathrm{~cm}$ sebagai wadah snack Ukuran $28 \times 7 \times 6 \mathrm{~cm}$ sebagai wadah rolling bread Ukuran $12,5 \times 16,5 \times 7 \mathrm{~cm}$ sebagai wadah snack Ukuran $25 \times 16,5 \times 7 \mathrm{~cm}$ sebagai wadah snack Ukuran $22 \times 22 \times 8 \mathrm{~cm}$ sebagai wadah kue mandarin Ukuran $24 \times 24 \times 7 \mathrm{~cm}$ sebagai wadah snack Ukuran $27 \times 27 \times 8 \mathrm{~cm}$ sebagai wadah snack Ukuran $25 \times 25 \times 10 \mathrm{~cm}$ sebagai wadah tart mini Ukuran $30 \times 30 \times 12 \mathrm{~cm}$ sebagai wadah tart bolu Ukuran $40 \times 40 \times 15 \mathrm{~cm}$ sebagai wadah tart besar kotak Ukuran $53 \times 39 \times 15 \mathrm{~cm}$ sebagai wadah tart besar panjang

Gambar 1. Infografis Kemasan Kardus Murni Bakery

Berdasarkan tabel di atas, mayoritas kemasan kardus roti Murni Bakery menggunakan satu bentuk desain kemasan saja (lihat gambar 1 hingga gambar 12, dan gambar 14). Pada kemasan no 13, Murni Bakery membuat sendiri secara manual kemasannya dengan bahan karton putih tanpa menambahkan unsur grafis. Alasan yang dikemukakan adalah untuk mencetak kemasan dengan ukuran tersebut masih terlalu mahal, termasuk kemasan no.14 yang sudah tidak dicetak lagi karena alasan biaya produksi yang tinggi. 
Kemasan kardus roti Murni Bakery memiliki 3 kerangka dasar yang berbeda. Rangka 1 dan 2 merupakan satu bagian yang menyambung, sedangkan untuk rangka 3 merupakan 2 bagian yang terpisah antara tutup dengan alasnya. Rangka 3 dibuat dua kali untuk setiap kardus, di mana tutup dan alas memiliki bentuk yang sama. Rangka 1 dan 3 memerlukan staples untuk menyusunnya, sedangkan rangka 2 tidak memerlukannya. Kemasan yang menggunakan rangka 1 adalah kemasan nomor 1, 2, 6, 7,9 , dan 10. Kemasan yang menggunakan rangka nomor 2 adalah kemasan nomor 3 dan 4. Sedangkan kemasan yang menggunakan rangka 3 adalah kemasan nomor 5, 8, 11, 12, 13, dan 14. Tidak diketahui mengapa Murni Bakery menggunakan 3 rangka yang berbeda dimana ketika rangka selesai disusun, semuanya memiliki bentuk yang sama yaitu balok.

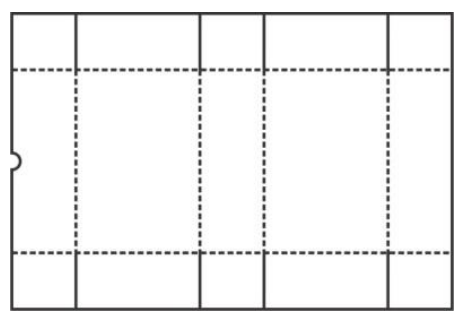

Rangka 1

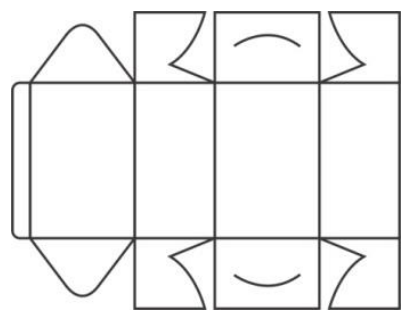

Rangka 2

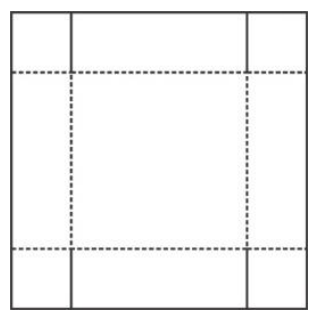

Rangka 3

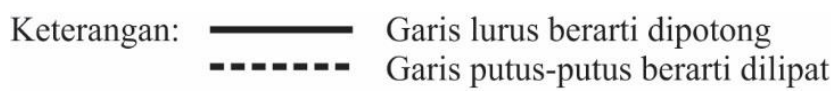

Gambar 2. Kerangka Kemasan Kardus Murni Bakery

Bentuk balok dianggap bentuk yang praktis dan sudah sangat umum digunakan sebagai kemasan kardus roti pada bakery. Kardus dipilih oleh Pak Soerjono karena dianggap lebih prestise sehingga ketika orang membeli untuk digunakan sebagai pemberian atau pada acara khusus terlihat lebih sopan dan pantas. Menurut Wirya (1999:29-30), secara umum, bentuk kemasan yang sederhana lebih disukai karena konsumen cenderung melihat bentuk dari segi kepraktisannya. Dalam hal ini kemasan kardus Murni Bakery sudah cukup baik karena balok merupakan bentuk yang sederhana. Cara penggunaan kemasan pun mudah, karena hanya berupa sistem buka dan tutup.

\subsection{Analisis Ilustrasi Kemasan Murni Bakery}

Kemasan kardus roti Murni Bakery tidak menggunakan ilustrasi, tetapi menggunakan elemen dasar desain berupa garis horizontal dan diagonal berwarna oranye dan coklat. Elemen grafis dapat digunakan untuk menuntun konsumen melalui desain kemasan dengan mengarahkan mata untuk membaca hirarki informasi (Klimchuk, 2006:131). Kemasan nomor 2 menggunakan bentuk hati yang dilubangi dan diberi lapisan plastik pada sisi atas kemasan, sehingga membuat kemasan nomor 2 berbeda dengan kemasan kardus lainnya. Dalam hal ini Pak Soerjono tidak memiliki alasan yang jelas mengapa menggunakan garis horizontal, diagonal, maupun bentuk hati pada kemasan 
kardus roti Murni Bakery sehingga tidak dapat diketahui apa maksud dan tujuan penggunaannya.

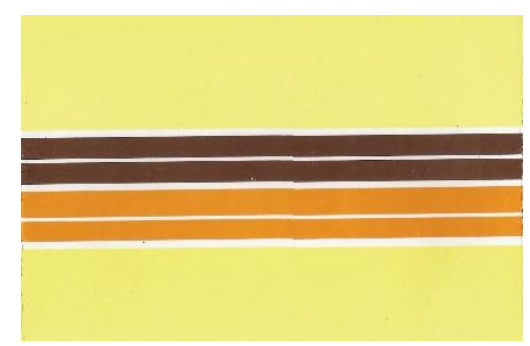

Tampak Atas

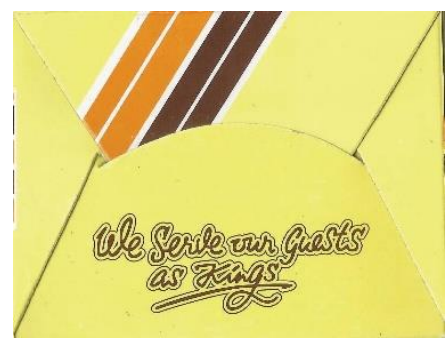

Tampak Kanan dan Kiri

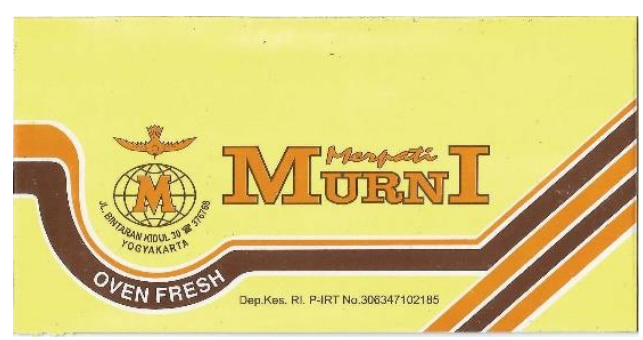

Tampak Depan dan Belakang

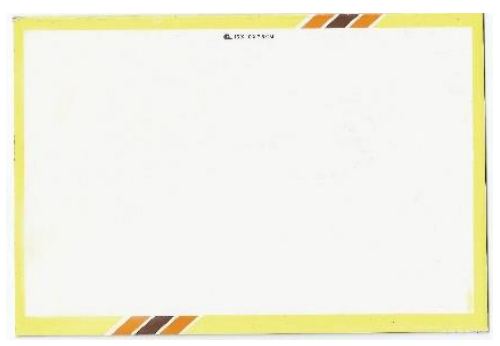

Tampak Bawah

Gambar 3. Tampilan Kemasan Kardus Murni Bakery

Berdasarkan penelitian yang ditulis oleh Lakoro (2002), ilustrasi dapat dimanfaatkan sebagai daya tarik melalui gaya ikonik serta pengolahan elemen tipografi dan fotografi pada desain kemasan makanan. Sedangkan Klimchuk dan Krasovec (2006:125) menyebutkan bahwa fotografi dengan mencantumkan produk yang ditata dengan piring yang sesuai dan perlengkapannya mampu membangkitkan selera makan, dan memberi daya tarik pada kemasan.

\subsection{Analisis Tipografi Kemasan Murni Bakery}

Dalam analisis tipografi pada kemasan kardus Murni Bakery pembahasan lebih ditekankan pada kategorisasi jenis huruf yang digunakan serta keterbacaan informasi yang ada pada kemasan. Berikut ini tabel klasifikasinya: 
Tabel 3. Tipografi pada Kemasan Kardus Murni Bakery

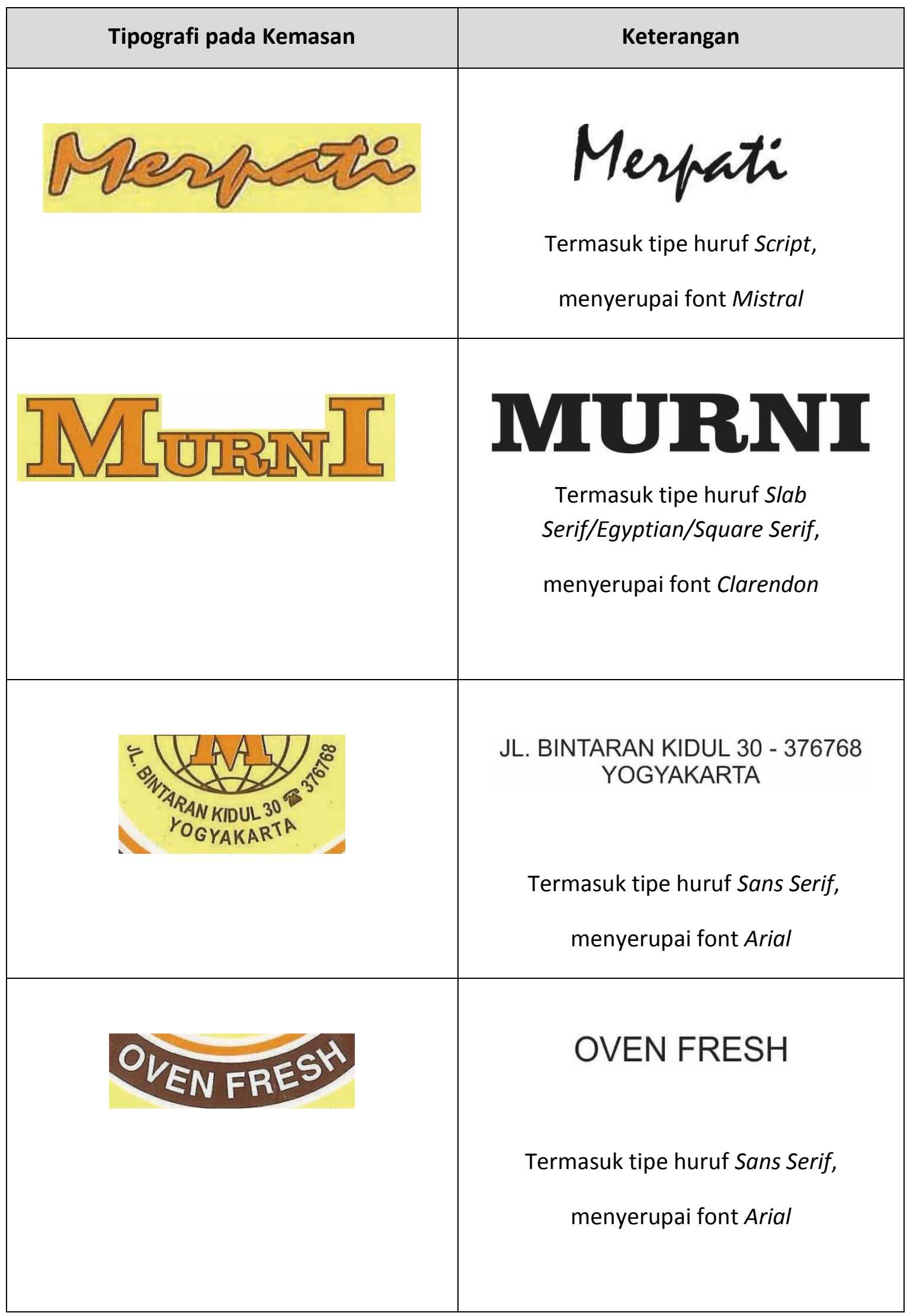




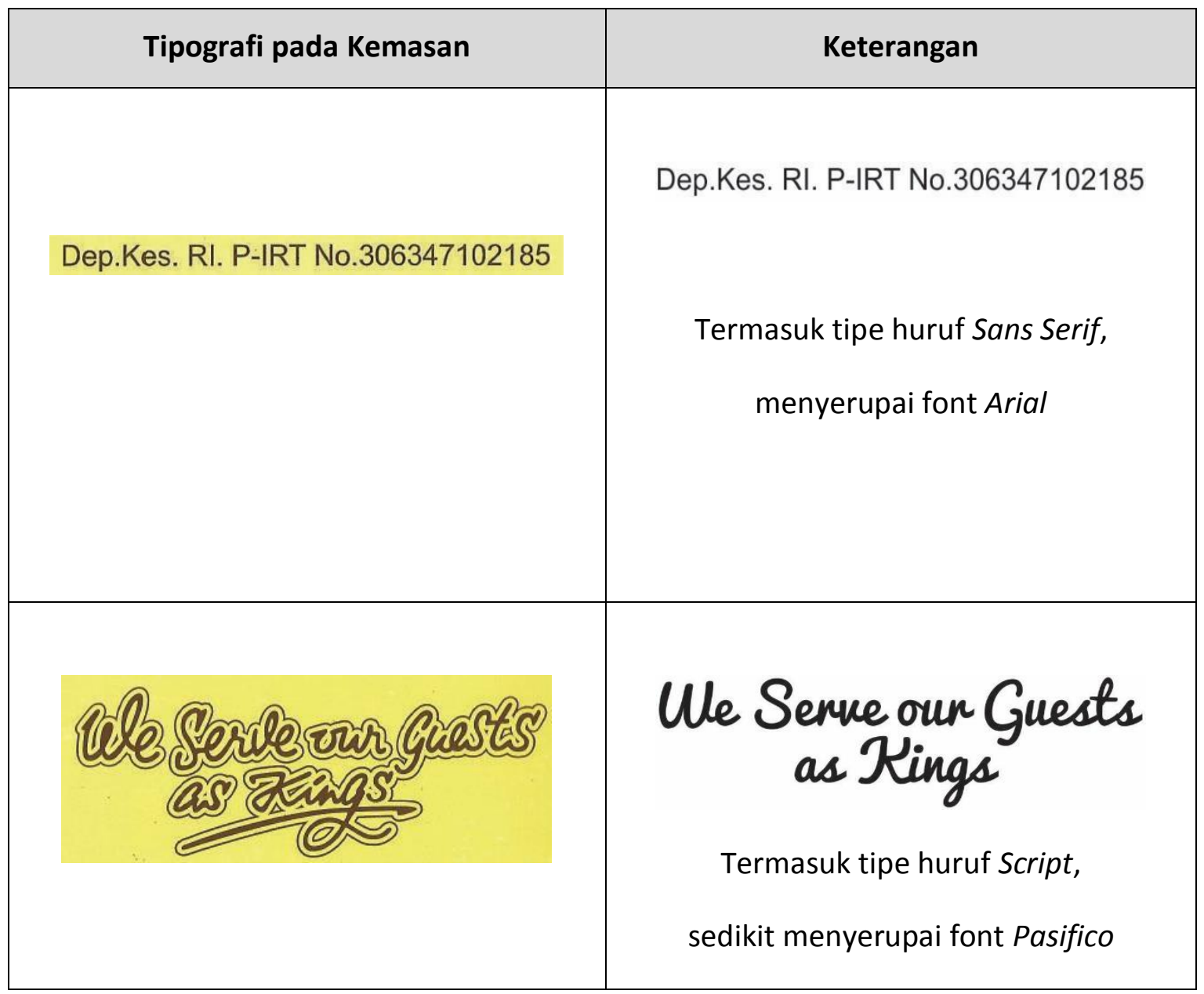

Berdasarkan tabel di atas, dapat dilihat bahwa kemasan kardus Murni Bakery menggunakan tipe huruf yang bervariasi diantaranya Script, Slab Serif/ Egyptian/ Square Serif, dan Sans Serif. Pada kemasan kardus roti Murni Bakery terdapat beberapa teks. Yang pertama merupakan nama dari perusahaan yaitu "Merpati MURNI" yang sudah menjadi bagian dari merek perusahaan. Tulisan "Merpati" menggunakan tipe huruf script yang menyerupai font Mistral, sedangkan tulisan "MURNI" menggunakan tipe huruf Slab Serif yang menyerupai font Clarendon. Kedua jenis font ini memiliki sifat yang bertolak belakang di mana yang satu tampak dinamis (Merpati) sedangkan yang satu lagi tampak kokoh, kaku, dan kuat (MURNI).

Kemudian terdapat teks alamat Murni Bakery yaitu "JL. BINTARAN KIDUL 30 376768", kata "OVEN FRESH", dan kata "Dep.Kes. RI. P-IRT No.306347102185" yang menggunakan tipe huruf Sans Serif yang menyerupai font Arial. Pada kata "OVEN FRESH", pesan yang ingin disampaikan adalah produk Murni Bakery selalu fresh atau segar seperti baru matang dari oven sehingga baik dan nikmat untuk dikonsumsi. Tetapi penggunaan kata tersebut kurang tepat karena memiliki makna yang ambigu, karena dapat diartikan "oven baru" dalam bahasa Indonesia. Pada kemasan kardus Murni Bakery juga terdapat slogan "We Serve our Guests as Kings" yang berarti kami memberikan layanan prima (seperti raja) pada para pelanggan, menggunakan tipe huruf Script yang sedikit menyerupai font Pasifico. 
Secara keseluruhan, kemasan kardus Murni Bakery menggunakan jenis font yang kontras dan beragam serta memiliki tingkat keterbacaan tinggi yang memudahkan konsumen dalam membaca informasi yang tertera pada kemasan. Ukuran teksnya pun sudah diurutkan dengan baik sehingga dapat dibaca secara berurutan menurut prioritas informasinya, dimana merk memiliki ukuran yang paling besar lalu diikuti oleh slogan, teks "OVEN FRESH", alamat, dan nomor P-IRT. Perkecualian pada slogan "We Serve our Guests as Kings" yang menggunakan font script yang terlalu tebal dan diberikan tambahan outline sehingga bekesan rumit dan keterbacaannya rendah.

\subsection{Analisis Tata Letak/Layout Kemasan Murni Bakery}

Tata letak elemen visual pada kemasan kardus Murni Bakery meliputi merek dan teks. Merek Murni Bakery diletakkan pada bagian depan dan belakang kemasan dengan warna yang cukup kontras dengan latar belakang dan ukuran cukup besar sehingga dapat terlihat dengan jelas. Tetapi perlu dipertimbangkan kembali apakah pada bagian atas kemasan perlu diberi merek, karena ketika akan mengkonsumsi produk, konsumen akan melihat kemasan dari atas. Sedangkan bagian sisi atas kemasan tidak mengandung merek atau informasi apapun. Kemudian teks pada sisi depan dan belakang kemasan sudah diletakkan dengan urutan yang baik, sehingga tampak mana yang ingin ditonjolkan terlebih dahulu. Slogan Murni Bakery yang diletakkan pada bagian samping kanan dan kiri kemasan cukup menarik perhatian karena tidak terdapat teks lain.

Tabel 4. Tata Letak Elemen Visual Kemasan Kardus Murni Bakery

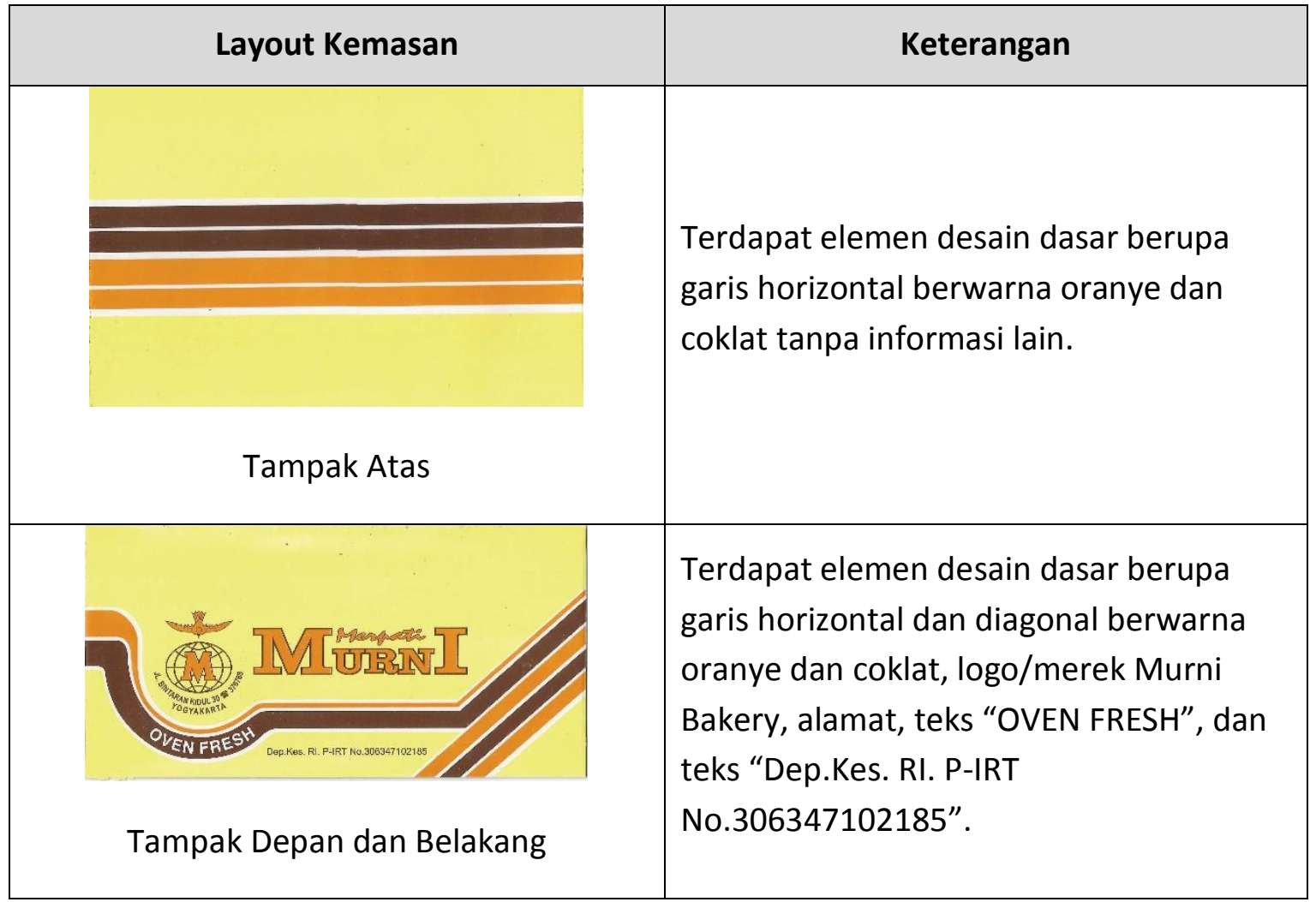




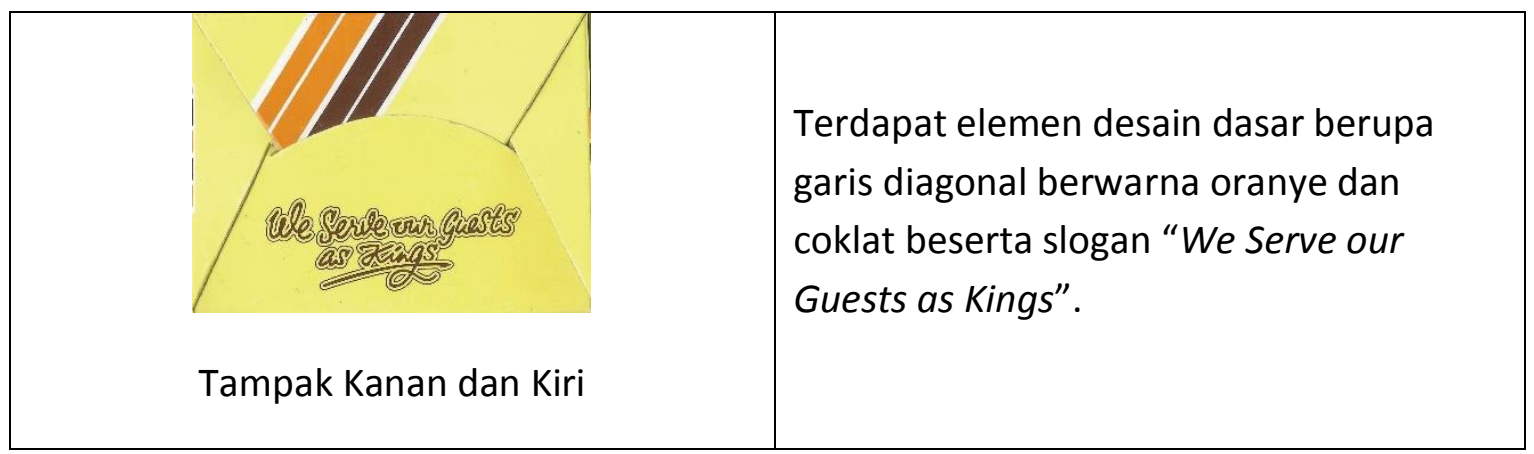

Pada bagian alamat, ada perbedaan letak pada kemasan-kemasan kardus tersebut. Pada kemasan nomor 1, 3, 6, 7, 8, dan 12, alamat terletak di bawah tulisan "Merpati Murni". Sedangkan pada kemasan nomor 4, 5, 9, 10, 11, dan 14, alamat terletak di bawah logo Murni Bakery dengan posisi melengkung mengikuti bentuk dari logo tersebut. Namun sebaiknya alamat tidak dituliskan di bawah logo terlalu dekat karena dapat menimbulkan persepsi bahwa alamat tersebut merupakan bagian dari logo.

Tabel 5. Perbedaan Letak Alamat Kemasan Kardus Murni Bakery

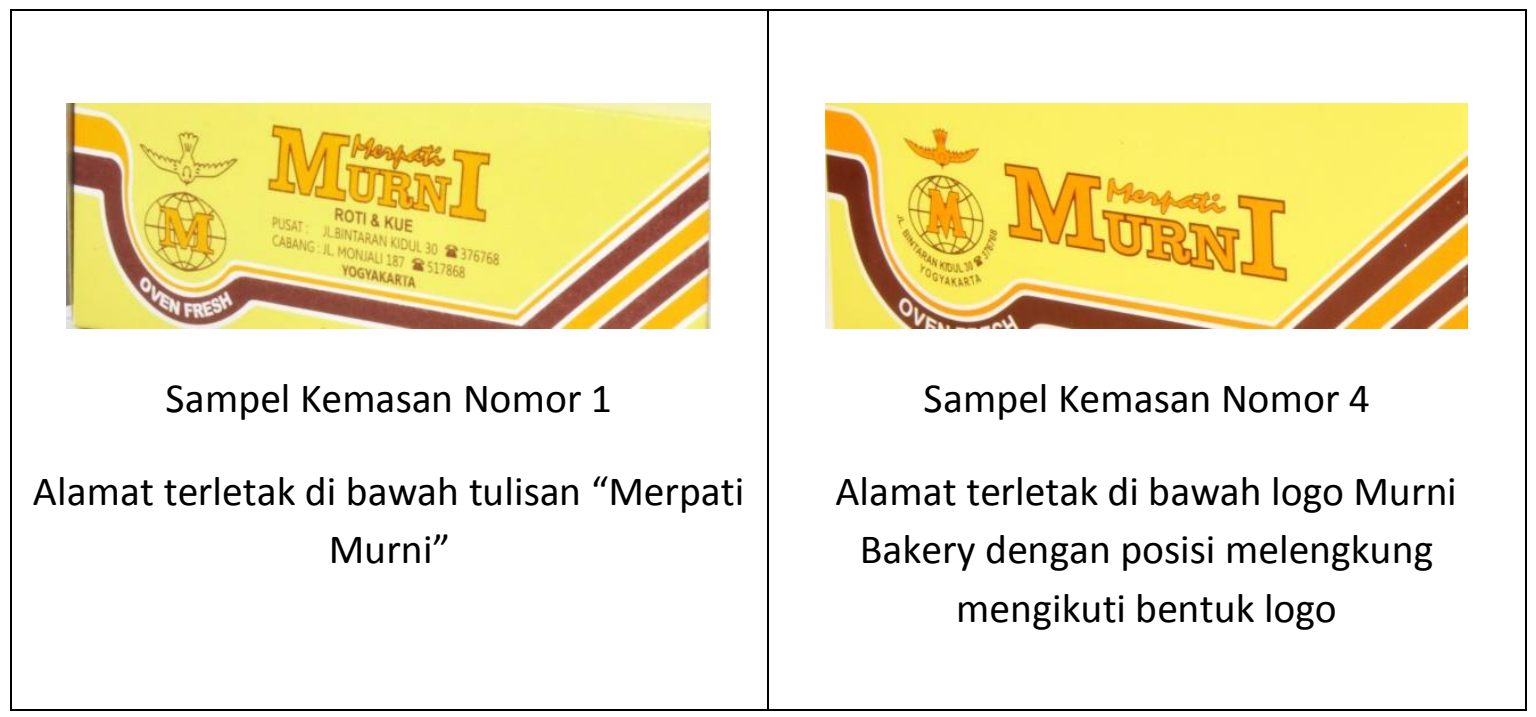

Kemudian pada kemasan nomor 2 pada bagian depan, nama Merpati Murni, logo, dan alamat diletakkan pada bagian tengah dengan alamat terletak di bawah logo Murni Bakery. Sedangkan pada bagian belakang, logo terletak di sebelah kiri dengan nama Merpati Murni, logo, alamat, dan nomor P-IRT di sebelah kanan. Tidak diketahui mengapa hanya pada kemasan nomor 2 saja yang bagian depan berbeda dengan bagian belakang.

Secara keseluruhan, tata letak elemen visual pada kemasan kardus Murni Bakery sudah cukup baik. Dapat terlihat dengan kejelasan urutan prioritas informasi yang ingin disampaikan oleh Murni Bakery. 


\section{KESIMPULAN DAN SARAN}

\subsection{Kesimpulan}

Kemasan memiliki fungsi yang tidak lagi berupa daya tarik praktis saja tetapi juga daya tarik visual dimana desain kemasan memiliki peran yang penting untuk menarik perhatian konsumen. Pada kemasan Roti Murni daya tarik utama ditemukan pada warna Kuning yang menjadi ciri khas kemasannya. Melalui analisis data yang telah dilakukan, dapat diambil kesimpulan sebagai berikut:

1. Desain kemasan kardus Murni Bakery sudah lama tidak mengalami perubahan karena Murni Bakery tidak memiliki divisi khusus yang menangani desain kemasan produk rotinya.

2. Desain kemasan kardus Murni Bakery tidak seluruhnya sesuai dengan teori kemasan Desain Komunikasi Visual. Salah satu penyebabnya karena Murni Bakery tidak memiliki divisi khusus yang menangani desain kemasannya. Pak Soerjono selaku pemilik Murni Bakery sudah tidak dapat mengingat kembali siapa yang pertama kali mendesain kemasan kardus Murni Bakery. Dari hasil Analisis Komponensial menggunakan teori desain komunikasi visual berupa teori warna, bentuk, ilustrasi, tipografi, dan tata letak menghasilkan simpulan sebagai berikut:

a. Pemahaman konsep warna kemasan antara versi Murni Bakery dengan versi teori DKV berbeda, tetapi penggunaan warna pada kemasan roti Murni sudah sesuai dengan kaidah teori warna kemasan (sesuai dengan produk di dalamnya). Warna Kuning pada kemasan roti Murni yang dikombinasikan dengan warna coklat dan oranye telah menjadi Brand yang sangat kuat.

b. Bentuk kemasan kardus Murni Bakery berupa balok sederhana memudahkan penggunaan kemasannya.

c. Kemasan kardus Murni Bakery belum mengoptimalkan pemanfaatan ilustrasi dengan baik sehingga tampilan visual kemasannya kurang menunjang produk.

d. Secara keseluruhan, kemasan kardus Murni Bakery menggunakan jenis font yang beragam, terlalu bervariasi sehingga nampak kurang seragam. Tingkat keterbacaan dan kontras fontnya tinggi, kecuali pada slogan "We Serve our Guests as Kings" yang bekesan rumit sehingga rendah keterbacaannya.

e. Tata letak elemen visual pada kemasan kardus Murni Bakery sudah cukup baik.

\subsection{Saran}

1. Penggunaan ilustrasi atau foto produk Roti Murni dengan tambahan minuman pendamping; seperti secangkir teh atau kopi yang membangkitkan selera konsumen dapat dijadikan alternatif ide untuk memperkuat tampilan visual kemasan Murni Bakery.

2. Diperlukan penggantian tipe huruf Script yang memiliki keterbacaan yang tinggi pada kalimat "We Serve our Guests as Kings" , karena pilihan huruf Script yang digunakan saat ini terlalu rumit sehingga kurang dapat dibaca dengan baik

3. Penggunaan bahasa asing seperti pada kalimat "fresh from the oven" dan "We Serve our Guests as Kings" perlu diperbaiki tata bahasanya agar tidak menimbulkan kesalahan persepsi.

4. Tata letak merek dan alamat Murni Bakery harus konsisten agar kemasan Murni Bakery lebih menarik dan komunikatif. 


\section{DAFTAR PUSTAKA}

\section{Buku}

Bungin, Burhan.2007.Penelitian Kualitatif Komunikasi, Ekonomi, Kebijakan Publik, dan IImu Sosial Lainnya Edisi Kedua.Jakarta: Prenada Media Group.

Danger, EP. 1992.Memilih Warna kemmasan.Jakarta;Institut PPM

Julianti, Sri.2014.The Art of Packaging. Jakarta: PT Gramedia Pustaka Utama.

Klimchuk, Marianne Rosner dan Krasovec, Sandra A. 2006. Desain Kemasan:

Perencanaan Merek Produk yang Berhasil Mulai dari Konsep sampai

Penjualan. Jakarta: Erlangga.

Rustan, Surianto.2009. Mendesain Logo. Jakarta: PT Gramedia Pustaka Utama.

Wirya, Iwan.1999. Kemasan yang Menjual. Jakarta: PT Gramedia Pustaka Utama.

\section{Artikel Jurnal}

Cenadi, Christine Suharto.2000. Peranan Desain Kemasan Dalam Dunia Pemasaran. NIRMANA. Vol 2:92-103.

Lakoro, Rahmatsyam.2002.Studi Komunikasi Visual Pada Kemasan Makanan Ringan. (http://personal.its.ac.id/files/pub/.pdf diakses 9 Mei 2016 pukul 10.45 WIB) Natadjaja, Listia.2007. Analisa Elemen Grafis Desain Kemasan Indomie Goreng Pasar Lokal dan Ekspor. NIRMANA.Vol 9:20-30.

Prathama, Nico Yudha dan Setianto, Dodi. 2015.Analisis Elemen Visual Kemasan Chiki Snack. Dimensi. Vol 12:241-252. 